\title{
EVALUASI PENGARUH PRODUCT QUALITY, PRODUCT INNOVATION DAN MARKETING PROMOTION TERHADAP BRAND IMAGE IKEA
}

\section{[Evaluation of the Influence of Product Quality, and Product Innovation Marketing Promotion for the IKEA Brand Image]}

\author{
I Gede Wisnu Satria Chandra Putra ${ }^{1)}$ \\ ${ }^{1)}$ Program Studi Bisnis Digital, Universitas Bunda Mulia \\ Diterima 28-08-2020 / Disetujui 31-05-2021
}

\begin{abstract}
This research aimed to analyze the influence of Product Quality, Product Innovation and Marketing Promotion to Brand Image. The object of this research is consumer of IKEA in Alam Sutra - Tangerang. This research was done to 100 respondents by using convenience sampling technique and using the SPSS 22.00 program as a data processing. The result of this research shows that simultaneously, the variable of Product Quality, Product Innovation and Marketing Promotion influence the Brand Image of IKEA in Alam Sutra Tangerang. It has been proven from the result of $(F)$ simoultant test. However the result of $(t)$ partial test shows significant point on one of three independent variables that supports the hipothesis. Therefore, the accepted assumption is, there is influence only between Product Innovation to Brand Image of IKEA in Alam SutraTangerang
\end{abstract}

Keywords: Product Quality, Product Innovation, Marketing Promotion, Brand Image

\begin{abstract}
ABSTRAK
Penelitian ini bertujuan untuk menganalisis pengaruh Kualitas Produk, Inovasi Produk dan Promosi Pemasaran terhadap Citra Merek. Objek penelitian ini adalah konsumen IKEA di Alam Sutra - Tangerang. Penelitian ini dilakukan pada 100 responden dengan menggunakan teknik convenience sampling dan menggunakan program SPSS 22.00 sebagai alat pengolahan data. Hasil penelitian ini menunjukkan bahwa secara simultan variabel Kualitas Produk, Inovasi Produk, dan Promosi Pemasaran memengaruhi Citra Merek IKEA di Alam Sutra - Tangerang. Ini telah dibuktikan dari hasil uji simultan (F). Namun hasil (t) uji parsial menunjukkan titik signifikan pada salah satu dari tiga variabel independen yang mendukung hipotesis. Oleh karena itu, asumsi yang diterima adalah, hanya ada pengaruh antara Inovasi Produk dengan Citra Merek IKEA di Alam Sutra - Tangerang
\end{abstract}

Kata kunci: Kualitas Produk, Inovasi Produk, Promosi dan Pemasaran, Citra Merek

\section{PENDAHULUAN}

\section{A. Latar Belakang Penelitian}

IKEA pada awalnya terbentuk pada tahun 1943 di negara asalnya Swedia yang fokus menjual perabot rumah tangga. Kemudian perusahaan asal Swedia tersebut melihat segmentasi pasar di Indonesia dengan menggandeng perusahaan lokal PT Hero Supermarket Tbk. sebagai pemegang lisensi resmi IKEA di Indonesia. Pada tanggal 15
Oktober 2014 IKEA Alam Sutra resmi membuka gerai pertamanya di Indonesia yang merupakan cabang ke-364 dan yang paling baru di 46 negara di dunia pada saat itu. IKEA juga menjalin kerja sama dengan industri lokal dengan mengambil bahan baku dan pengrajin dari Solo dan Yogjakarta. Produk - produk lokal tersebut kemudian akan dipasarkan IKEA ke pasar Internasional.

Dengan hadirnya IKEA, pasar perabot rumah tangga dan mebel di Indonesia semakin

\footnotetext{
*Korespondensi Penulis:

E-mail: iputra@bundamulia.ac.id
} 
kompetitif. Dengan menyasar segmentasi menengah keatas, IKEA mengusung konsep sebagai perusahaan retail perabot rumah tangga dan mebel dengan harga yang terjangkau dan memiliki desain yang elegan. Selain itu, IKEA juga menggabungkan nilai fungsi, desain, dan kualitas namun dengan harga yang terjangkau dan bermanfaat bagi semua orang.

Pada dasarnya, IKEA memiliki visi untuk menciptakan kehidupan sehari-hari yang lebih baik bagi banyak orang dengan menyediakan produk yang berkualitas dengan harga yang terjangkau. IKEA juga dikenal dengan inovasi mereka dengan menyediakan produk inovatif yang berbeda dengan produk perabot rumah tangga / mebel pada umumnya. Dalam hal ini, IKEA memanfaatkan berbagai media promosi untuk menyampaikan visi misi dan brand image mereka ke masyarakat.

Namun dengan berjalan nya waktu, visi misi yang menjadi landasan awal IKEA untuk masuk ke pasar Indonesia tidak tersampaikan dengan baik ke masyarakat Indonesia itu sendiri. Berdasarkan beberapa review dalam berbagai forum di internet, menyatakan bahwa IKEA lebih dikenal "hanya" sebagai tempat untuk melihat konsep tata ruang dan mebel yang bagus karena mereka menampilkan berbagai mock-up konsep ruangan di gerai mereka. Hal ini menyebabkan IKEA dianggap hanya merupakan tempat yang cocok untuk berfoto. Ada berbagai spot dalam IKEA yang sering dijadikan latar belakang foto baik itu bagi masyarakat atau bahkan para selebgram.

Selain itu, IKEA juga lebih dikenal oleh masyarakat Indonesia dari sisi kulinernya. Kuliner yang disediakan di IKEA dikenal memiliki cita rasa yang enak dan harga yang terjangkau. Bahkan dalam berbagai media promosi mereka seperti dalam Website atau Radio, IKEA sering menyebutkan promo kuliner mereka sebagai senjata utama dalam menarik pelanggan untuk berkunjung ke IKEA. Namun dampaknya, hal ini mengubah motivasi utama masyarakat untuk datang ke
IKEA menjadi hanya untuk mencari makan atau sekedar melakukan pertemuan di Food Court tanpa adanya keinginan untuk membeli produk utama dari IKEA itu sendiri yaitu perabot rumah tangga dan mebel.

Lalu, berdasarkan berbagai diskusi yang ada di beberapa forum-forum yang membahas produk-produk mebel atau perabot rumah tangga, banyak yang berpendapat bahwa kualitas produk IKEA masih belum sesuai dengan harga yang diberikan. Menurut mereka apabila dibandingkan dengan produk dari kompetitor lain yang sejenis, mereka bisa mendapat produk yang kualitasnya lebih baik dengan harga yang sama seperti yang diterapkan oleh IKEA.

Dari berbagai permasalahan ini terlihat bahwa ada ketidaksesuaian antara persepsi masyarakat mengenai IKEA dengan Brand Image yang ingin dibangun oleh IKEA sendiri. IKEA yang harusnya dikenal dengan produknya yang berkualitas dan inovatif dengan harga terjangkau, malah menjadi lebih dikenal sebagai tempat rekreasi / kuliner dan produknya dianggap kualitasnya kurang dibandingkan produk lain dengan harga lebih murah.

Permasalahan ini didukung oleh penelitian sebelumnya yang dilakukan oleh (Rizky, 2019) yang meneliti mengenai pengaruh citra merek IKEA kepada keputusan pembelian produk IKEA di Indonesia. Dari penelitian tersebut diperoleh hasil bahwa citra merek tidak memiliki pengaruh signifikan terhadap keputusan pembelian produk IKEA. Berdasarkan hal ini terlihat bahwa memang ada kesenjangan atau gap antara citra merek IKEA di Indonesia dengan produk mereka sendiri.

Oleh karena itu penelitian ini dilakukan untuk mengetahui ada tidaknya pengaruh dari beberapa faktor yang sejalan dengan Visi Misi IKEA terhadap Brand Image IKEA pada masyarakat di Indonesia serta untuk membuktikan ada tidaknya kesalahan 
yang dilakukan IKEA dalam membangun brand image mereka.

\section{B. Rumusan Masalah}

Berdasarkan latar belakang tersebut rumusan masalah dalam penelitian ini dijabarkan sebagai berikut:

a. Apakah Product Quality, Product Inovation, dan Marketing Promotion berpengaruh signifikan positif terhadap Brand Image IKEA di Indonesia secara simultan?

b. Apakah Product Quality berpengaruh signifikan positif terhadap Brand Image IKEA di Indonesia secara parsial?

c. Apakah Product Inovation berpengaruh signifikan positif terhadap Brand Image IKEA di Indonesia secara parsial?

d. Apakah Marketing Promotion berpengaruh signifikan positif terhadap Brand Image IKEA di Indonesia secara parsial?

\section{TINJAUAN PUSTAKA}

\section{A. Brand Image}

Brand Image merupakan fenomena subjektif dan perseptual yang terbentuk dari interpretasi pelanggan terhadap suatu brand, baik secara beralasan maupun emosional (Dobni \& Zinkhan, 1990). Karena itu, Brand Image merupakan konsep brand yang ditentukan oleh customer. Brand Image sendiri tidak berhubungan dengan teknis, fisik dan fungsi produk secara langsung, melainkan dibentuk oleh aktivitas pasar dan hal-hal lainnya. Hal ini menunjukkan bahwa persepsi customer terhadap suatu produk lebih penting dibandingkan dengan produk itu sendiri (Thimothy, 2016).

Dalam mengukur Brand Image, terdapat beberapa dimensi yang dapat dijadikan tolak ukur (Davidson, 1998). , yaitu

- Reputation, yaitu nama baik dari suatu merek produk tertentu.

- Recognition, yaitu tingkat pengenalan konsumen terhadap suatu merek.
- Affinity, yaitu hubungan secara emosional antara konsumen terhadap suatu merek.

- Brand Loyalty, yaitu seberapa jauh kesetiaan konsumen dalam menggunakan produk dari merek tersebut.

\section{B. Product Quality}

Kualitas produk merupakan karakteristik suatu produk atau jasa yang bergantung pada kemampuannya untuk memuaskan kebutuhan konsumen baik secara implisit maupun eksplisit (Kotler, 2007). Dengan kata lain dapat dinyatakan bahwa kualitas produk merupakan tingkat baik buruknya suatu produk dalam kemampuannya untuk memenuhi kebutuhan dan harapan konsumen.

Dalam mengukur kualitas produk, Garvin mengatakan terdapat 8 dimensi kualitas produk (Garvin, 1987), yaitu:

- Performance, yaitu kinerja produk dalam menjalankan fungsinya.

- Features, yaitu berkaitan dengan kelengkapan fungsi pada produk

- Reliability, yaitu kemungkinan keberhasilan produk dalam menjalankan fungsinya dalam periode atau kondisi tertentu.

- Conformance, yaitu kesesuaian produk dengan spesifikasi yang diinginkan konsumen

- Durability, yaitu daya tahan atau masa pakai dari produk tersebut

- Serviceability, yaitu berkaitan dengan pelayanan dan kemudahan perbaikan produk

- Aesthetic, yaitu berkaitan dengan penampilan dan desain produk

- Perceived Quality, yaitu berkaitan dengan persepsi konsumen saat menggunakan produk.

\section{Product Innovation}

Inovasi produk merupakan proses dalam menciptakan suatu barang atau jasa yang dianggap sebagai sesuatu yang baru. 
Inovasi produk tidak hanya dilakukan untuk menciptakan produk baru, namun dapat meliputi pengembangan produk yang sudah ada agar dapat memiliki fungsi tambahan yang baru (Kotler \& Keller, 2009).

Dalam mengukur Product Innovation, terdapat 5 dimensi yang dapat mempengaruhi tingkat inovasi (Kotler, P. \& Armstrong, 2008) yakni:

- Keunggulan relatif adalah tingkat yang menunjukkan keunggulan hasil inovasi terhadap produk yang telah ada.

- Kompatibilitas adalah tingkat kesesuaian hasil inovasi dengan nilai dan pengalaman calon konsumen.

- Kompleksitas dalah tingkat kesulitan hasil inovasi untuk dimengerti atau digunakan.

- Divisibilitas adalah tingkat hasil inovasi dapat dicoba sedikit demi sedikit

- Komunikabilitas adalah tingkat kemampuan hasil penggunaan inovasi dapat diobservasikan atau dijelaskan kepada orang lain.

\section{Marketing Promotion}

Promosi adalah usaha perusahaan untuk mempengaruhi konsumen dengan melakukan Persuasive Communication melalui segala unsur acuan atau bauran pemasaran (Simamora, 2007). Dapat dikatakan pula bahwa promosi merupakan suatu usaha untuk menginformasikan dan mempengaruhi konsumen sehingga tertarik untuk membeli produk.

Terdapat beberapa dimensi promosi yang mencadi acuan (Kotler, P. \& Armstrong, 2008) yaitu

- Advertising, yaitu bentuk komunikasi yang dilakukan untuk menginformasikan dan mempengaruhi target pasar melalui berbagai media.

- Sales Promotion, yaitu insentif jangka panjang yang ditawarkan kepada konsumen untuk merangsang datangnya pembelian produk tersebut. Seperti pemberian diskon atau produk gratis.
- Public Relation, yaitu usaha atau upaya untuk menarik perhatian yang positif dari masyarakat terhadap perusahaan

- Direct Marketing, yaitu suatu bentuk promosi secara langsung dengan cara memasarkan produk atau barang agar mendapatkan reaksi secara langsung dari konsumen

\section{E. Kerangka Konseptual dan Hipotesis}

Berdasarkan berbagai teori yang telah dikumpulkan, peneliti membuat kerangka konseptual (conceptual framework) sebagai berikut

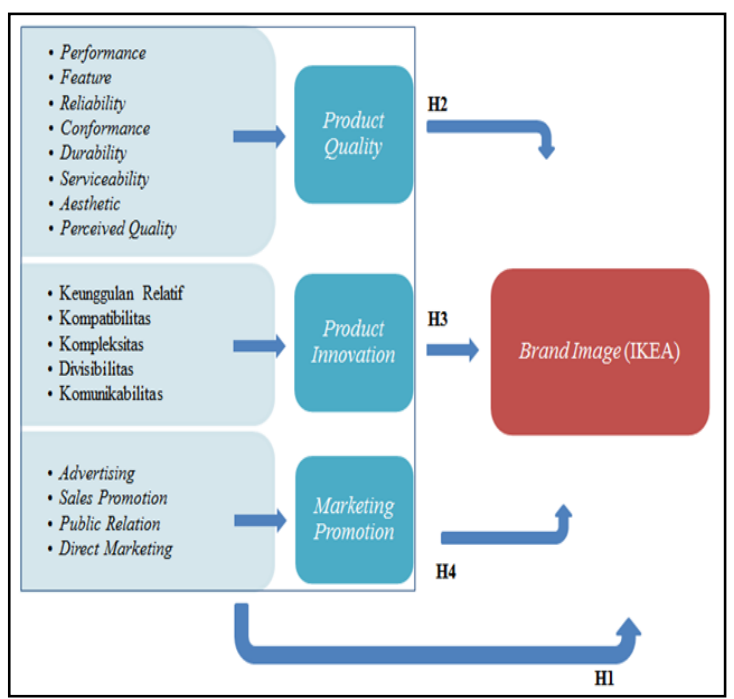

Gambar 1. Kerangka Konseptual Penelitian Sumber: Dokumen Pribadi

Dalam kerangka konseptual penelitian, terdapat tiga variabel bebas yaitu Product Quality, Product Innovation dan Marketing Promotion. Masing-masing variabel memiliki berbagai dimensi yang akan dijadikan dasar pembuatan kuisioner. Lalu terdapat satu variabel terikat yaitu Brand Image yang dalam hal ini adalah Brand Image dari IKEA. Lalu tanda panah menunjukan hubungan antara variabel bebas dan variabel terikat yang dijadikan dasar untuk menyusun hipotesis penelitian.

Dalam penelitian ini, terdapat beberapa hipotesis yang menggambarkan pengaruh antar variabel seperti berikut: 
- $\quad \mathrm{H}_{0} 1$ : Product Quality, Product Innovation dan Marketing Promotion tidak berpengaruh secara signifikan positif terhadap Brand Image IKEA

Ha1: Product Quality, Product Innovation dan Marketing Promotion berpengaruh secara signifikan positif terhadap Brand Image IKEA

- $\mathrm{H}_{0}$ 2: Product Quality tidak berpengaruh signifikan positif terhadap Brand Image IKEA

Ha2: Product Quality berpengaruh signifikan positif terhadap Brand Image IKEA

- $\mathrm{H}_{0}$ 3: Product Innovation tidak berpengaruh signifikan positif terhadap Brand Image IKEA

Ha3 : Product Innovation berpengaruh signifikan positif terhadap Brand Image IKEA

- $\mathrm{H}_{0} 4$ : Marketing Promotion tidak berpengaruh signifikan positif terhadap Brand Image IKEA

Ha4: Marketing Promotion berpengaruh signifikan positif terhadap Brand Image IKEA

\section{METODE PENELITIAN}

\section{A. Instrumen Penelitian}

Dalam penelitian ini, pengambilan data dilakukan menggunakan teknik convenience sampling yaitu teknik sampling dengan memilih sampel tanpa melalui pertimbangan apapun. Seseorang diambil sebagai sampel karena kebetulan orang sedang pada lokasi dan waktu yang sama dengan lokasi dan waktu pengambilan sampel.

Adapun instrumen penelitian yang digunakan untuk mengumpulkan data yang dibutuhkan dalam penelitian ini adalah menggunakan kuisioner yang dibentuk berdasarkan dimensi dan elemen dari masingmasing variabel penelitian dalam conceptual framework. Kuisioner ini disebarkan pada beberapa titik di IKEA Alam Sutera.

\section{B. Teknik Analisa Data}

Analisa data dalam penelitian ini dilakukan dengan dengan melakukan Uji Validitas, Uji Reliabilitas dan Uji Hipotesis (Analisa Koefisien Determinasi, Uji F dan Uji T) secara statistik dengan bantuan aplikasi SPSS. Secara umum Uji Validitas dilakukan untuk mengukur ketepatan setiap item dalam kuisioner sedangkan Uji Reliabilitas dilakukan untuk mengukur konsistensi dari alat ukur yang digunakan. Sedangkan Uji Hipotesis dilakukan untuk mengetahui adanya pengaruh antara variabel bebas terhadap variabel terikat. (Sugiyono, 2018)

\section{HASIL DAN PEMBAHASAN}

\section{A. Karakteristik Responden}

Dalam proses pengambilan sampel, data yang berhasil diperoleh sebanyak 80 responden yang pernah berkunjung ke IKEA. Berdasarkan pada analisa data secara deskriptif, dari 80 responden tersebut hanya 40 responden yang pernah membeli produk IKEA. Sebagian besar dari responden yang pernah membeli produk IKEA merupakan karyawan dengan tingkat penghasilan lebih dari 3 juta per bulan.

Responden yang diperoleh, 65\% tinggal di rumah pribadi yang berlokasi di daerah Tangerang, Tangerang Selatan dan DKI Jakarta. Dalam mendukung penelitian ini, kami hanya menggunakan data yang valid yaitu data responden yang pernah membeli produk IKEA sebanyak 40 data karena penelitian ini mengukur Product Quality dan Product Innovation yang tidak mungkin diketahui jika tidak pernah membeli produk IKEA.

\section{B. Hasil Uji Validitas Data}

Dalam menguji validitas data, penulis melakukan perhitungan nilai Pearson's Correlation dari masing-masing pertanyaan yang mewakili setiap variabel, lalu kemudian dibandingkan dengan nilai $r$ table (Sugiyono, 2018) yang dalam kasus ini memiliki nilai 
sebesar 0.3. Apabila nilai Pearson's Correlation lebih besar dari nilai $r$ table, maka data dianggap valid.

Tabel 1. Hasil Uji Validitas Brand Image

\begin{tabular}{llll}
\hline \multirow{2}{*}{ No } & Pernyataan & \multicolumn{2}{l}{ Uji Validitas } \\
\cline { 3 - 4 } & & $\begin{array}{l}\text { Pearson's } \\
\text { Correlation }\end{array}$ & Hasil \\
\hline 1 & Q1 & 0.530 & Valid \\
\hline 2 & Q2 & 0.386 & Valid \\
\hline 3 & Q3 & 0.498 & Valid \\
\hline 4 & Q4 & 0.465 & Valid \\
\hline 5 & Q5 & 0.559 & Valid \\
\hline 6 & Q6 & 0.671 & Valid \\
\hline 7 & Q8 & 0.661 & Valid \\
\hline 8 & Q9 & 0.518 & Valid
\end{tabular}

Sumber : Hasil Pengolahan Data (2019)

Dari tabel 1 dapat dilihat bahwa validitas kuisioner dari variabel Brand Image yang disebarkan kepada responden semua nilainya lebih besar dari 0.3 (Nilai $\mathrm{r}$ table). Sehingga disimpulkan bahwa seluruh penyataan-pernyataan pada kuisioner yang mewakili variabel Brand Image adalah valid dalam mendefinisikan variabel Brand Image.

Tabel 2. Hasil Uji Validitas Product Quality

\begin{tabular}{llll}
\hline \multirow{2}{*}{ No } & Pernyataan & \multicolumn{2}{l}{ Uji Validitas } \\
\cline { 3 - 4 } & & $\begin{array}{l}\text { Pearson's } \\
\text { Correlation }\end{array}$ & Hasil \\
\hline 1 & Q7 & 0.686 & Valid \\
\hline 2 & Q11 & 0.512 & Valid \\
\hline 3 & Q12 & 0.635 & Valid \\
\hline 4 & Q13 & 0.742 & Valid \\
\hline 5 & Q14 & 0.626 & Valid \\
\hline 6 & Q15 & 0.830 & Valid \\
\hline 7 & Q16 & 0.746 & Valid \\
\hline 8 & Q17 & 0.633 & Valid \\
\hline
\end{tabular}

\begin{tabular}{llll}
\hline 9 & Q18 & 0.750 & Valid \\
\hline 10 & Q19 & 0.607 & Valid \\
\hline 11 & Q20 & 0.768 & Valid \\
\hline 12 & Q21 & 0.644 & Valid
\end{tabular}

Sumber : Hasil Pengolahan Data (2019)

Dari tabel 2 dapat dilihat bahwa validitas kuisioner dari variabel Product Quality yang disebarkan kepada responden semua nilainya lebih besar dari 0.3 (Nilai $r$ table). Namun untuk pertanyaan ke 10 (Q10) dihilangkan karena saat perhitungan memiliki nilai dibawah $r$ table sehingga pertanyaan tersebut tidak valid dan mengganggu pendefinisian dari variabel. Sehingga disimpulkan bahwa penyataan-pernyataan pada kuisioner yang mewakili variabel Product Quality selain Q10 adalah valid dalam mendefinisikan variabel Product Quality.

\section{Tabel 3. Hasil Uji Validitas Product Innovation}

\begin{tabular}{llll}
\hline \multirow{2}{*}{ No } & Pernyataan & \multicolumn{2}{l}{ Uji Validitas } \\
\cline { 3 - 4 } & & $\begin{array}{l}\text { Pearson's } \\
\text { Correlation }\end{array}$ & Hasil \\
\hline 1 & Q22 & 0.718 & Valid \\
\hline 2 & Q23 & 0.503 & Valid \\
\hline 3 & Q24 & 0.324 & Valid \\
\hline 4 & Q25 & 0.687 & Valid \\
\hline 5 & Q26 & 0.735 & Valid \\
\hline 6 & Q27 & 0.591 & Valid
\end{tabular}

Sumber : Hasil Pengolahan Data (2019)

Dari tabel 3 dapat dilihat bahwa validitas kuisioner dari variabel Product Innovation yang disebarkan kepada responden semua nilainya lebih besar dari 0.3 (Nilai $r$ table). Namun untuk pertanyaan ke 28 (Q28) dan 29 (Q29) dihilangkan karena saat perhitungan memiliki nilai dibawah $r$ table sehingga pertanyaan tersebut tidak valid dan mengganggu pendefinisian dari variabel.

Sehingga disimpulkan bahwa penyataan-pernyataan pada kuisioner yang mewakili Product Innovation selain Q28 dan 
Q29 adalah valid dalam mendefinisikan variabel Product Innovation tersebut.

Tabel 4. Hasil Uji Validitas Marketing Promotion

\begin{tabular}{llll}
\hline \multirow{2}{*}{ No } & Pernyataan & \multicolumn{2}{l}{ Uji Validitas } \\
\cline { 3 - 4 } & & $\begin{array}{l}\text { Pearson's } \\
\text { Correlation }\end{array}$ & Hasil \\
\hline 1 & Q31 & 0.718 & Valid \\
\hline 2 & Q32 & 0.353 & Valid \\
\hline 3 & Q33 & 0.788 & Valid \\
\hline 4 & Q34 & 0.793 & Valid \\
\hline 5 & Q35 & 0.717 & Valid \\
\hline
\end{tabular}

Sumber : Hasil Pengolahan Data (2019)

Dari tabel 4 dapat dilihat bahwa validitas kuisioner dari variabel Marketing Promotion yang disebarkan kepada responden semua nilainya lebih besar dari 0.3 (Nilai $r$ table). Namun untuk pertanyaan ke 30 (Q30) dihilangkan karena saat perhitungan memiliki nilai dibawah $r$ table sehingga pertanyaan tersebut tidak valid dan mengganggu variabel.

Sehingga disimpulkan bahwa penyataan-pernyataan pada kuisioner yang mewakili variabel Marketing Promotion selain Q30 adalah valid dalam mendefinisikan variabel Marketing Promotion.

\section{Hasil Uji Reliabilitas Data}

Setelah melalui pengujian validitas dan proses eliminasi data, kemudian dilakukan pengujian reliabilitas untuk membuktikan bahwa sampel data yang telah diambil reliable dan mampu menggambarkan setiap variabel dalam penelitian ini.

Pengujian realibilitas dilakukan dengan menghitung nilai Cronbach Alpha dari seluruh data yang mewakili suatu variabel (Sugiyono, 2018). Berikut adalah hasil perhitungan nilai Cronbach Alpha dari masing-masing variabel yang ditampilkan pada tabel 5 .
Tabel 5. Hasil Uji Reliabilitas

\begin{tabular}{llll}
\hline Variabel & $\begin{array}{l}\mathrm{N} \text { of } \\
\text { Items }\end{array}$ & $\begin{array}{l}\text { Cronbach } \\
\text { Alpha }\end{array}$ & Hasil \\
\hline $\begin{array}{l}\text { Brand } \\
\text { Image }\end{array}$ & 8 & 0.640 & Reliable \\
\hline $\begin{array}{l}\text { Product } \\
\text { Quality }\end{array}$ & 12 & 0.889 & Reliable \\
\hline $\begin{array}{l}\text { Product } \\
\text { Innovation }\end{array}$ & 6 & 0.638 & Reliable \\
\hline $\begin{array}{l}\text { Marketing } \\
\text { Promotion }\end{array}$ & 5 & 0.696 & Reliable \\
\hline
\end{tabular}

Sumber : Hasil Pengolahan Data (2019)

Pengujian reliabilitas ini dilakukan dengan mencari nilai cronbach's alpha. Jika nilai cronbach's alpha lebih besar dari 0.60, menurut (Ghozali, 2016) maka disimpulkan bahwa pernyataan-pernyataan dalam instrument tersebut reliable. Berdasarkan table 5 , dapat dilihat bahwa intrumen pada keempat variabel seluruhnya dinyatakan reliable karena memiliki nilai cronbach's alpha lebih besar dari 0.60 .

\section{Hasil Uji Hipotesis}

Pengujian hipotesis ini dilakukan melalui pengujian dengan metode multiple regression analysis, untuk menguji signifikansi simultan (Uji Statistik F) dan uji signifikansi parameter individual (Uji Statistik t). Kedua pengujian ini dilakukan untuk melihat tingkat signifikansi hubungan antar variabel baik secara simultan maupun secara parsial.

Secara simultan, pengujian dilakukan untuk menguji hipotesis $\mathrm{H}_{0} 1$ untuk melihat ada tidaknya pengaruh dari seluruh variabel secara keseluruhan bebas terhadap variabel terikat. Sedangkan secara parsial pengujian dilakukan untuk menguji hipotesis $\mathrm{H}_{0} 2$, hipotesis $\mathrm{H}_{0} 3$ dan hipotesis $\mathrm{H}_{0} 4$ untuk melihat ada tidaknya pengaruh antara masing-masing variabel bebas penelitian secara individu terhadap variabel terikat (Sugiyono, 2018). 
Tabel 6. Analisa Koefisien Determinasi

\begin{tabular}{ccccc}
\hline Model & $\mathrm{R}$ & $\begin{array}{c}\mathrm{R} \\
\text { Square }\end{array}$ & $\begin{array}{c}\text { Adjusted } \\
\text { R Square }\end{array}$ & $\begin{array}{c}\text { Std Error } \\
\text { of The } \\
\text { Estimate }\end{array}$ \\
\hline 1 & 0.722 & 0.521 & 0.481 & 2.0107 \\
\hline
\end{tabular}

Sumber : Hasil Pengolahan Data (2019)

Pada tabel 6 dapat terlihat bahwa nilai $\mathrm{R}^{2}$ pada analisa independent variabel sebesar 0.521 . Hal ini menunjukkan bahwa faktor Product Quality, Product Innovation dan Marketing Promotion dapat mempengaruhi Brand Image sebesar $52.1 \%$ sedangkan sisanya $47.9 \%$ dapat dipengaruhi oleh faktor faktor lain di luar dari ruang lingkup dalam penelitian ini. Hal ini menunjukkan bahwa ketiga faktor dalam penelitian ini memiliki potensi dampak yang signifikan terhadap Brand Image IKEA karena dampaknya lebih dari $50 \%$.

Tabel 7. Hasil Pengujian Hipotesis Simultan

\begin{tabular}{lrrrrr}
\hline Model & $\begin{array}{c}\text { Sum of } \\
\text { Squares }\end{array}$ & df & $\begin{array}{r}\text { Mean } \\
\text { Square }\end{array}$ & F & Sig \\
\hline Regression & 158.227 & 3 & 57.742 & 13.045 & 0.000 \\
\hline Residual & 145.548 & 36 & 4.043 & & \\
\hline Total & 303.775 & 39 & & & \\
\hline
\end{tabular}

Sumber : Hasil Pengolahan Data (2019)

Pada tabel 7 secara simultan atau bersama sama dapat dijelaskan pengaruh antar variabel independen yaitu Product Quality (X1), Product Innovation (X2), dan Marketing Promotion (X3) terhadap Brand Image (Y). Pada tabel tersebut diperoleh bahwa nilai $\mathrm{F}$ statistik yang diperoleh sebesar 13.045, sedangkat nilai $\mathrm{F}$ critical sebesar 2.87 dengan tingkat signifikan 0,000 .

Karena nilai $\mathrm{F}$ lebih besar dari $\mathrm{F}$ critical (13.045 > 2.87 ) atau tingkat signifikan lebih kecil dari $0.05(0.000<0.05)$ maka $\mathrm{H}_{0} 1$ ditolak dan Ha1 diterima. Artinya terdapat suatu pengaruh yang signifikan antara Product Quality, Product Innovation dan Marketing Promotion terhadap Brand Image IKEA secara simultan.
Seperti yang telah terlihat dalam analisa koefisien determinasi, ketiga faktor ini memiliki tingkat pengaruh lebih dari 50\% terhadap variabel Brand Image IKEA dan hal ini semakin diperkuat dengan hasil pengujian hipotesis secara simultan yang menunjukan adanya pengaruh yang signifikan dari variabel bebas secara keseluruhan terhadap variabel terikat.

Tabel 8. Hasil Pengujian Hipotesis Parsial

\begin{tabular}{|c|c|c|c|c|c|}
\hline \multirow[b]{2}{*}{ Model } & \multicolumn{2}{|c|}{$\begin{array}{l}\text { Unstandarized } \\
\text { Coefficients }\end{array}$} & \multirow{2}{*}{$\begin{array}{l}\text { Standarized } \\
\text { Coefficients } \\
\text { Beta }\end{array}$} & \multirow[b]{2}{*}{$\mathrm{t}$} & \multirow[b]{2}{*}{ Sig } \\
\hline & B & $\begin{array}{l}\text { Std. } \\
\text { Error }\end{array}$ & & & \\
\hline (Constant) & 16.354 & 3.500 & & 4.673 & 0.000 \\
\hline $\begin{array}{l}\text { Product } \\
\text { Quality }\end{array}$ & 0.113 & 0.056 & 0.241 & 2.022 & 0.051 \\
\hline $\begin{array}{l}\text { Product } \\
\text { Innovation }\end{array}$ & 0.571 & 0.115 & 0.651 & 4.941 & 0.000 \\
\hline $\begin{array}{l}\text { Marketing } \\
\text { Promotion }\end{array}$ & \multicolumn{4}{|c|}{ Promotion } & 0.540 \\
\hline \multicolumn{6}{|c|}{ Sumber : Hasil Pengolahan Data (2019) } \\
\hline $\begin{array}{l}\text { (t-test) } \mathrm{d} \\
\text { Innovati } \\
\text { Brand It } \\
\text { masing-1 }\end{array}$ & $\begin{array}{l}\text { da tab } \\
\text { i vari } \\
\text { dan } 1 \\
\text { age. B } \\
\text { asing }\end{array}$ & $\begin{array}{l}8 \text { ter } \\
\text { bel } P r \\
\text { larketi } \\
\text { rikut } \\
\text { ariabel }\end{array}$ & $\begin{array}{l}\text { ihat hasil } \\
\text { duct Qua } \\
\text { g Promot } \\
\text { dalah pem }\end{array}$ & $\begin{array}{l}\text { ji statis } \\
\text { ty, Pro } \\
\text { on terha } \\
\text { ahasan }\end{array}$ & $\begin{array}{l}\text { ik t } \\
\text { duct } \\
\text { dap } \\
\text { per }\end{array}$ \\
\hline
\end{tabular}

Variabel Product Quality (X1) memiliki nilai $\mathrm{t}$ sebesar 2.022 dengan signifikansi sebesar 0.051 . Karena nilai signifikan $\mathrm{t}$ lebih besar dari 0.05 (0.051 > 0.05 ) atau nilai $t$ statistik lebih kecil dari $t$ critical $(2.022<2.0281)$ maka diambil keputusan untuk menerima hipotesis nol $\left(\mathrm{H}_{0} 2\right)$ yang menyatakan bahwa Product Quality tidak berpengaruh secara signifikan terhadap Brand Image IKEA.

Variabel Product Innovation (X2) memiliki nilai $\mathrm{t}$ sebesar 4.941 dengan signifikansi sebesar 0.000 . Karena nilai signifikan t lebih kecil dari $0.05(0.000<0.05)$ atau nilai $\mathrm{t}$ statistik lebih besar dari $\mathrm{t}$ critical (4.941 > 2.0281) maka diambil keputusan untuk menolak $\mathrm{H}_{0} 3$ dan menerima $\mathrm{Ha} 3$ yang menyatakan bahwa Product Innovation 
berpengaruh secara signifikan terhadap Brand Image IKEA.

Variabel Marketing Promotion (X3) memiliki nilai $\mathrm{t}$ sebesar -0.618 dengan signifikansi sebesar 0.540 . Karena nilai signifikan $\mathrm{t}$ lebih besar dari 0.05 (0.540 > $0.05)$ atau nilai $t$ statistik lebih kecil dari $t$ critical $(-0.618<2.0281)$ maka diambil keputusan untuk menerima hipotesis nol $\left(\mathrm{H}_{0} 4\right)$ yang menyatakan bahwa Marketing Promotion tidak berpengaruh secara signifikan terhadap Brand Image IKEA.

\section{SIMPULAN}

Berdasarkan hasil analisis dan pembahasan yang telah diuraikan pada bab sebelumnya, maka penulis dapat simpulkan bahwa

- Terdapat suatu pengaruh yang signifikan antara Product Quality, Product Innovation dan Marketing Promotion terhadap Brand Image IKEA secara simultan.

- Product Quality tidak berpengaruh secara signifikan terhadap Brand Image IKEA.

- Product Innovation berpengaruh secara signifikan terhadap Brand Image IKEA.

- Marketing Promotion tidak berpengaruh secara signifikan terhadap Brand Image IKEA.

Dari simpulan diatas terlihat bahwa hanya faktor Product Innovation sajalah yang memiliki pengaruh secara signifikan terhadap Brand Image dari IKEA di Indonesia. Hal ini menunjukan IKEA masih memiliki reputasi yang baik dalam hal menciptakan dan memasarkan produk yang inovatif. Masyarakat Indonesia terbukti masih menganggap produk IKEA sebagai produk yang Inovatif dan menjadi daya tarik tersendiri dibandingkan dengan kompetitor lain.

Namun, komitmen IKEA dalam menciptakan produk berkualitas masih kurang memiliki pengaruh kepada Brand Image IKEA di Indonesia. IKEA Indonesia masih dianggap belum bisa menjadikan kualitas produk sebagai kelebihan mereka dibandingkan dengan kompetitor. Hal ini sejalan dengan pembicaraan di berbagai forum yang masih menganggap kualitas produk IKEA masih tergolong kurang dan hal ini perlu diperhatikan oleh IKEA ke depannya.

Selain itu, strategi promosi dan pemasaran yang dilakukan oleh IKEA melalui media digital ataupun konvensional di Indonesia masih belum bisa membentuk Brand Image IKEA secara signifikan. Hal ini bisa disebabkan oleh konten pemasaran IKEA yang masih belum begitu menggambarkan keunggulan dan visi dari IKEA karena sejauh ini mereka masih fokus pada promosi harga dan makanan yang sebenarnya diluar dari bisnis utama mereka. Oleh karena itu masih diperlukan perhatian khusus dari IKEA dalam melakukan strategi pemasaran yang tepat agar dapat lebih efektif dalam membangun Brand Image mereka di Indonesia.

Dalam penelitian ini terdapat keterbatasan dimana faktor yang diteliti hanya terbatas pada 3 faktor yang berkaitan dengan Visi IKEA saja, oleh karena itu pada penelitian selanjutnya disarankan untuk membahas lebih lanjut berbagai faktor lainnya yang berpotensi memiliki pengaruh terhadap Brand Image IKEA misalkan seperti faktor Harga Produk yang belum disorot dalam penelitian ini. Lalu untuk pengambilan data akan lebih baik jika jumlah responden diperbanyak dan jumlah lokasi IKEA yang menjadi objek penelitian juga ditambah mengingat gerai IKEA di Indonesia saat ini sudah ada 2 yaitu di daerah Alam Sutera dan Sentul City.

\section{DAFTAR PUSTAKA}

Davidson, H. (1998). The next generation of brand measurement. Journal of Brand Management. https://doi.org/10.1057/bm.1998.33

Dobni, D., \& Zinkhan, G. M. (1990). In Search of Brand Image: A Foundation 
Analysis. Advances in Consumer

Research.

Garvin, D. A. (1987). Competing on the Eight Dimensions of Quality Harvard Business Review Competing on the Eight Dimensions of Quality. Harvard Business Review.

Ghozali, I. (2016). Aplikasi Analisis Multivariate dengan Program IBM SPSS 23. (Edisi 8). Semarang: Badan Penerbit Universitas Diponegoro.

Kotler, P. \& Armstrong, G. (2008). PrinsipPrinsip Pemasaran. Edisi 12. Jilid 1. Manajemen Pemasaran.

Kotler, P. (2007). Dasar - dasar Pemasaran. Dasar-Dasar Pemasaran.

Kotler, P., \& Keller, K. L. (2009). Manajemen pemasaran Jilid 1. In Jakarta.

Rizky, M. B. (2019). PENGARUH CITRA MEREK, KERAGAMAN PRODUK, DAN KUALITAS PRODUK TERHADAP KEPUTUSAN PEMBELIAN DI IKEA. Universitas Mercu Buana Jakarta.

Simamora, H. (2007). Manajemen Pemasaran Internasional Jilid II Edisi 2 (2nd ed.). PT Rineka Cipta.

Sugiyono. (2018). Metode Penelitian Kombinasi (mixed Methods). In Alfabet.

Thimothy, S. (2016). Why Brand Image Matters More Than You Think. Forbes. 